\title{
RARE POSTPARTUM PRIMARY NECROTIZING FASCIITIS OF THE BREAST FOLLOWING MASTECTOMY: CASE REPORT
}

\author{
Fasciíte necrosante primária de mama rara no período \\ pós-parto seguida de mastectomia: relato de caso
}

\author{
Luiz Murillo Lopes de Britto', Maryane Chagas Barboza Brasilino², \\ Thazio Henrique Soares Cardoso de Souza², Michelly Nóbrega Monteiro', \\ Suzelle Freitas de Moura Oliveira1', Ricardo Ney Cobucci*
}

\section{ABSTRACT}

Primary necrotizing fasciitis (NF) of the breast is extremely rare. It progresses rapidly and can lead to sepsis and multi-organ failure without prompt medical and surgical management. Herein we describe the case of a healthy 42-year-old woman on the 10th day after cesarean section, who was admitted to the intensive care unit (ICU) with a painful and swollen right breast. It evolved rapidly in the ICU into septic shock and nipple discharge. She underwent immediate resuscitation followed by muscle-sparing right mastectomy. She was managed postoperatively in the ICU with intravenous antibiotic therapy. Complications included acute renal failure and anuria, leading to death on the fourth day after surgery. Prompt resuscitation and an aggressive surgical approach are critical to the successful management of this life-threatening pathology. Despite this, NF still carries a high mortality rate.

KEYWORDS: Breast; fasciitis, necrotizing; sepsis; mastectomy.

\section{RESUMO}

A fasciíte necrosante primária (FN) da mama é extremamente rara. Ela progride rapidamente e pode levar à sepse e à falência de múltiplos órgãos sem pronto atendimento médico e cirúrgico. Aqui descrevemos o caso de uma mulher saudável de 42 anos de idade no décimo dia pós cesárea, que foi admitida na unidade de terapia intensiva (UTI) com a mama direita dolorida e inchada. O quadro evoluiu rapidamente na UTI a choque séptico e descarga mamilar. Ela foi submetida a ressuscitação imediata seguida de mastectomia de mama direita com preservação muscular. Foi administrada terapia endovenosa com antibióticos na UTI durante o período pós-operatório. Complicações incluíram insuficiência renal aguda e anúria, levando à morte no quarto dia após a cirurgia. A reanimação imediata e uma abordagem cirúrgica agressiva são fundamentais para o sucesso do manejo dessa patologia que é ameaçadora. Apesar disso, a FN ainda carrega uma alta taxa de mortalidade.

PALAVRAS-CHAVE: Mama; faciite necrosante; sepse; mastectomia.

Study carried out at the Maternidade Escola Januário Cicco - Natal (RN), Brazil.

${ }^{1}$ Maternidade Escola Januário Cicco, Universidade Federal do Rio Grande do Norte - Natal (RN), Brazil.

2Universidade Federal do Rio Grande do Norte - Natal (RN), Brazil.

${ }^{3}$ Gynecology and Obstetrics Department, Universidade Potiguar - Natal (RN), Brazil.

*Corresponding author: rncobucci@unp.br

Conflict of interests: nothing to declare.

Received on: 04/28/2018. Accepted on: 07/14/2018 


\section{INTRODUCTION}

Necrotizing fasciitis (NF) is a surgical diagnosis characterized by friability of the superficial fascia, a notable absence of pus, and dishwater-gray exudate ${ }^{1}$. Developing in the lower or upper extremities, in the abdominal wall, the perineum and genital area, its swift clinical course is correlated with polymicrobial infection and synergy, which usually co-exist and rarely affects the breast ${ }^{2,3}$.

Necrotizing infections can occur after major traumatic injuries, as well as after varicella infection, non-penetrating soft-tissue injuries, minor breaches of the skin or mucosa, or routine obstetrical and gynecologic procedures; they can also occur in postsurgical and immunocompromised patients ${ }^{1}$.

Although it can occur at any site on the body, NF of the breast is extremely rare. It was first described in the literature by Shah et al. ${ }^{4}$ in 2001, and only a handful of cases have been published since then ${ }^{5}$. We present a case of primary NF of the breast in a healthy 42-year-old female patient.

\section{CASE REPORT}

A 42-year-old woman underwent cesarean section 10 days before, after a diagnosis of preeclampsia (gravida 2, para 2). She subsequently went to the clinic with a complaint of fever, chest pain and a painful and swollen right breast. It was dyspneic, with diffuse hyperemia and edema in the right breast; there was an axillary temperature of 39 degrees Celsius and oxygen saturation of $90 \%$ in ambient air.

Due to the dyspneic condition with low saturation, she was medicated with intravenous dipyrone and tenoxicam and transferred to the Emergency Department of a tertiary hospital.

On examination at this new hospital, there was an increased volume of her right breast with infectious signs (Figure 1), heart rate of 104 beats per minute, blood pressure of $80 / 60 \mathrm{mmHg}$, oxygen saturation of $97 \%$ under Venturimask, auscultation with a cracklein the right base and abdomen with a clean surgical wound, without signs ofinfection, painless and flaccid. Due to the hypothesis of puerperal mastitis with sepsis, the patient was admitted to the intensive care unit (ICU).

The patient arrived at ICU complaining of intense right breast pain, torporous, tachypneic, with a respiratory rate of 33 incursions per minute, axillary temperature of 33.8 degrees Celsius, heart rate of 120 beats per minute and blood pressure of 94 / $57 \mathrm{mmHg}$. Due to her condition, she was submitted to orotracheal intubation and material was collected for arterial gasometry, uroculture, blood culture and breast tissue culture (Table 1). In addition, volume expansion with analgesia, intravenous antibiotic therapy with ceftriaxone, oxacillin and clindamycin were initiated and the evaluation of mastology and breast ultrasonography was required. On the second day in ICU, the patient evolved with a lowering of consciousness level, oliguria, acidosis, with a hardened and swollen right breast. Ultrasound revealed a diffuse and subcutaneous edema, a thick content forming a small collection in one of the medial quadrants, estimated at $28 \mathrm{~mm}$, which may represent an inflammatory / infectious process.

The mastologist then decided on surgical intervention and a right mastectomy was performed (Figure 2). The anatomopathological study revealed absence of neoplasia, extensive areas of vascular congestion and tissue hemorrhage, stromal fibrosis and extensive acute mastitis (Figure 3). In the immediate postoperative period, the antibiotic regimen was changed to cefepime, vancomycin and clindamycin, but the condition worsened, with cyanosis of extremities, anuria, acute renal failure and septic shock resulting in patient's death on the fourth day after surgery.

\section{DISCUSSION}

Necrotizing fasciitis (NF) is a rare but aggressive soft tissue infection most commonly affecting the abdominal wall, perineum and extremities, being rare in the breast. It is characterized by widespread fascial necrosis with relative sparing of skin and muscle; it occurs more commonly in patients with comorbidities such as alcoholism, immunocompromise, intravenous drug use and diabetes mellitus. Streptococcus pyogenes is the most commonly implicated organism and it is cultured in approximately one

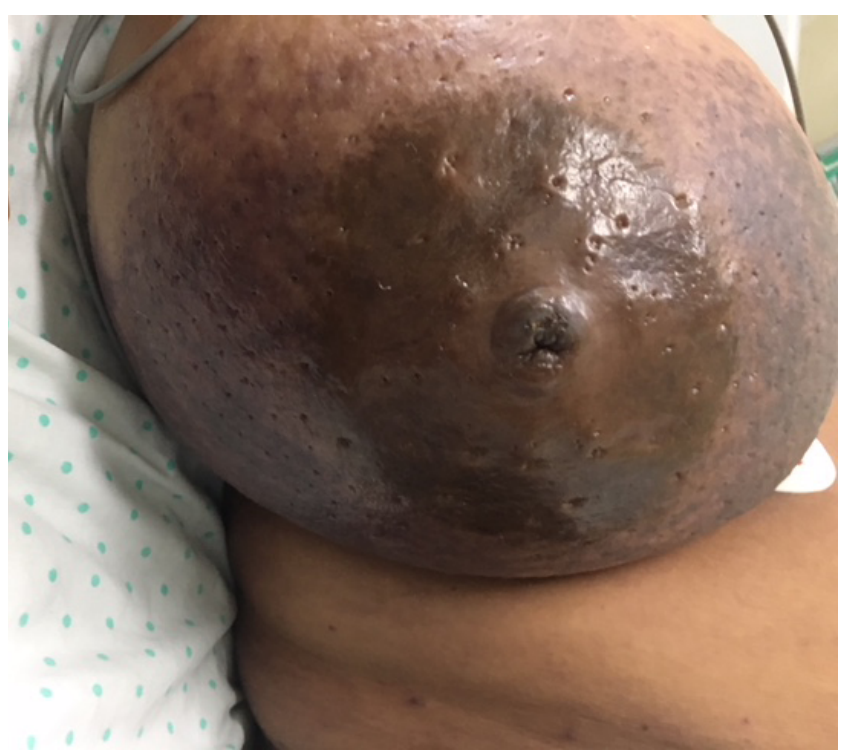

Figure 1. Frontal view of affected right breast.

Table 1. Intensive care unit (ICU) exams.

\begin{tabular}{l|c|c} 
Exam & Results & Reference values \\
Arterial gasometry & $\begin{array}{c}\mathrm{pH}=7.18 \\
\mathrm{pCO}_{2}=25.85\end{array}$ & $\begin{array}{c}\mathrm{pH}^{7.35}-7.45 \\
\mathrm{pCO}_{2} 35-45\end{array}$ \\
\hline Uroculture & Negative & Negative \\
\hline $\begin{array}{l}\text { Blood Culture } \\
\begin{array}{l}\text { Breast Tissue } \\
\text { Culture }\end{array}\end{array}$ & Negative & Negative \\
\hline
\end{tabular}




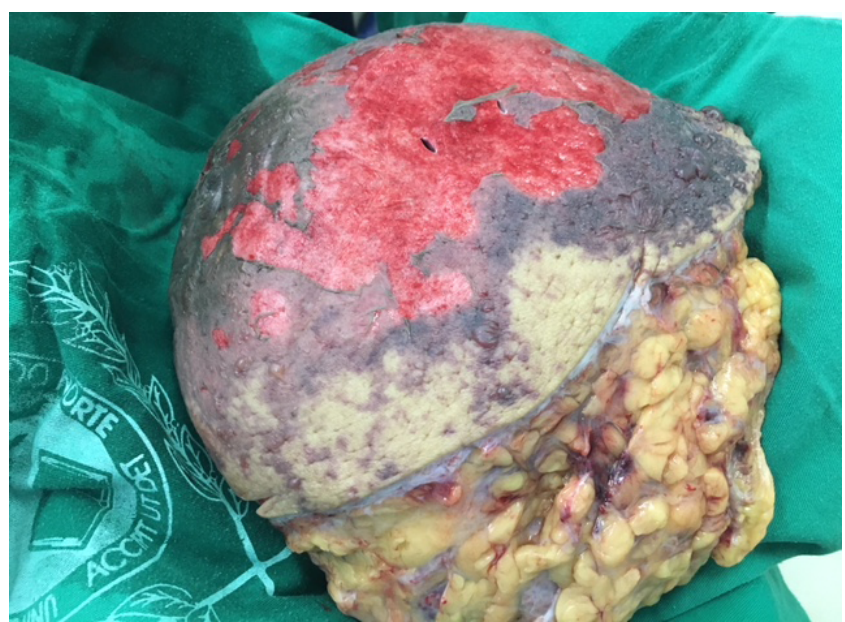

Figure 2. Wide surgical excision of necrotic tissue (right mastectomy).

third of cases 5 . We describe a case of NF in the right breast of a healthy woman after a cesarean section with all negative cultures.

Classic manifestations of NF include soft-tissue edema, erythema, severe pain, tenderness, fever and skin bullae or necrosis $^{1}$. The sonographic findings are fascia's irregularity, abnormal fluid collections along fascial planes, and diffuse thickening of the fascia ${ }^{6}$.

Only a few cases of necrotizing fasciitis in the breast $\mathrm{t}^{3-5,7-15}$ have been reported in the literature; and due to the high mortality rate, early recognition and surgical debridement are of absolute importance. Emergency surgical debridement of the affected tissues is the primary management modality for NF. Surgical management is indicated especially for patients with intense pain and changes of skin color (such as edema and/or ecchymoses), or in signs of skin ischemia with blisters and bullae. It is also indicated when the individual presents altered mental status, hypotension and metabolic acidosis, as in the case described ${ }^{2}$.

Although surgical treatment with mastectomy adopted in this case has been performed in other cases ${ }^{4,7,9,11,13}$, there have been reports of successful treatment with conservative surgery $y^{3,8,12,14,15}$ and even without surgery ${ }^{10}$. Lee et al. ${ }^{10}$ reported a case of NF of the breast in a pregnant woman successfully treated using negative-pressure wound therapy.

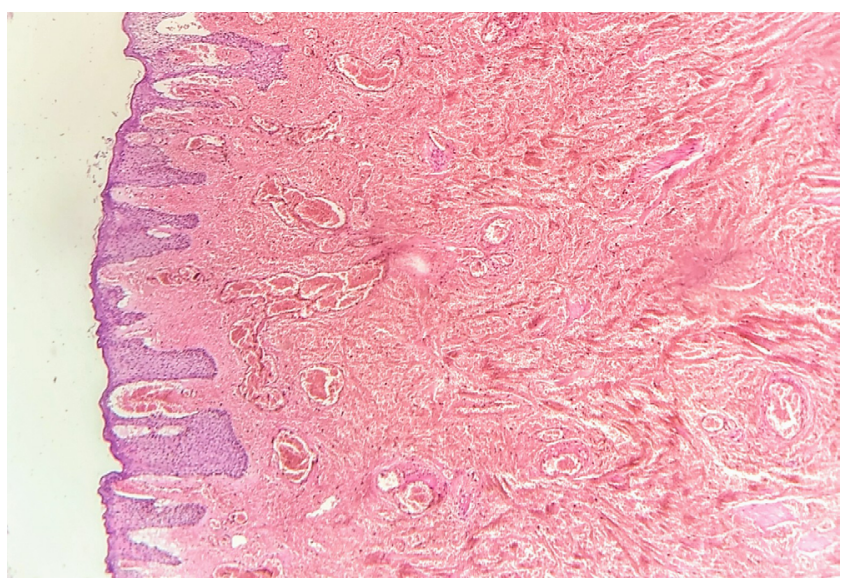

Figure 3. Histology showing extensive areas of vascular congestion and tissue hemorrhage (Haematoxylin and eosin stain - H\&E, X40 magnification).

Pharmacologic treatment for mixed aerobic and anaerobic infections of gynecologic organs should be based on Gram's staining, culture, and sensitivity tests. The Infectious Diseases Society of America (IDSA) publishes guidelines for the treatment of skin and soft-tissue infections. The current guidelines recommend vancomycin or linezolid in addition to one of the following therapies: piperacillin-tazobactam, carbapenem or ceftriaxonemetronidazole ${ }^{1}$. Some of these antibiotics were used in the case.

\section{CONCLUSION}

We present a rare case of primary NF of the breast with no history of tissue insult. The infection may be mistaken for cellulitis, puerperal mastitis or an abscess due to delayed cutaneous findings. Prompt diagnosis and rapid surgical intervention is crucial and can mean the difference between life and death in these critically ill patients. Despite this, NF still carries a high mortality rate.

\section{ACKNOLEDGMENTS}

We thank Dr. Francisco Pignataro Lima, Dr. Maria Julia de Paula Luiz and Dr. George Godeiro de Araújo Teixeira for performing the histologic study of the surgical excision of necrotic tissue.

\section{REFERENCES}

1. Stevens D, Bryant A. Necrotizing Soft-Tissue Infections. N Engl J Med. 2017;377(23):2253-65. http://doi.org/10.1056/NEJMral600673

2. Misiakos E, Bagias G, Patapis P, Sotiropoulos D, Kanavidis P, Machairas A. Current Concepts in the Management of Necrotizing Fasciitis. Front Surg. 2014;1:36. https://doi. org/10.3389/fsurg.2014.00036
3. Yang B, Connolly S, Ball W. Necrotising fasciitis of the breast: A rare primary case with conservation of the nipple and literature review. JPRAS Open. 2015;6:15-9. https://doi.org/10.1016/j.jpra.2015.05.002

4. Shah J, Sharma A, Johri A, Mearns B, O’Donoghue J, Thomas V. Necrotising fasciitis of the breast. Brit J Plastic Surg. 2001;54(1):67-79. http://doi.org/10.1054/bjps.2000.3461 
5. Fayman K, Wang K, Curran R. A case report of primary necrotising fasciitis of the breast: A rare but deadly entity requiring rapid surgical management. Int J Surg Case Rep. 2017;31:221-4. https://dx.doi.org/10.1016\%2Fj.ijscr.2017.01.049

6. Hanif M, Bradley M. Sonographic findings of necrotizing fasciitis in the breast. J Clin Ultrasound. 2008;36(8):517-9. https://doi.org/10.1002/jcu.20492

7. Nizami S, Mohiuddin K, Mohsin-e-Azam, Zafar H, Memon M. Necrotizing Fasciitis of the Breast. Breast J. 2006;12(2):168-9. https://doi.org/10.1111/j.1075-122X.2006.00227.x

8. Konik R, Cash A, Huang G. Necrotizing fasciitis of the breast managed by partial mastectomy and local tissue rearrangement. Case Reports Plast Surg Hand Surg. 2017;4(1):77-80. https://doi.org/10.1080/23320885.2017.1364970

9. Ward N, Harris J, Sloan D. Necrotizing Fasciitis of the Breast Requiring Emergent Radical Mastectomy. Breast J. 2016;23(1):95-9. https://doi.org/10.1111/tbj.12686

10. Lee J, Lee K, Sun W. Necrotizing fasciitis of the breast in a pregnant woman successfully treated using negative-pressure wound therapy. Ann Surg Treat Res. 2015;89(2):102-6. https:// dx.doi.org/10.4174\%2Fastr.2015.89.2.102

11. Yaji P, Bhat B, Harish E. Primary Necrotising Fasciitis of the Breast: Case Report and Brief Review of Literature. J Clin Diagn Res. 2014;8(7):ND01-2. https://dx.doi.org/10.7860\%2FJC DR\%2F2014\%2F9281.4558

12. Soliman M, Ayyash E, Aldahham A, Asfar S. Necrotizing Fasciitis of the Breast: A Case Managed without Mastectomy. Med Princ Pract. 2011;20(6):567-9. https://doi.org/10.1159/000330026

13. Angarita F, Acuna S, Torregrosa L, Tawil M, Sánchez E, Heilbron $\mathrm{O}$, et al. Bilateral necrotizing fasciitis of the breast following quadrantectomy. Breast Cancer. 2014;21(1):108-14. https://doi.org/10.1007/s12282-010-0219-4

14. Flandrin A, Rouleau C, Azar C, Dubon O, Giacalone P. First Report of a Necrotising Fasciitis of the Breast Following a Core Needle Biopsy. Breast J. 2009;15(2):199-201. https://doi. org/10.1111/j.1524-4741.2009.00697.x

15. Ablett D, Bakker-Dyos J, RaineyJ. Primary Necrotizing Fasciitis of the Breast: A Case Report and Review of the Literature. Scott Med J. 2012;57(1):60. https://doi.org/10.1258/smj.2011.011283 